\title{
Corporate Governance and Service Delivery in Nigeria's Corporate Affairs Commission: A Reflection on the 2001 Reform Exercise
}

\author{
Abdulrazak Yuguda Madu \\ Saidu Idris ${ }^{2}$

\begin{abstract}
${ }^{1}$ Ghazali Shafie Graduate School of Government, Universiti Utara Malaysia, 06010 Sintok, Kedah, Malaysia 2Department of Public Administration, Faculty of Management Sciences, Usmanu Danfodiyo University, Sokoto-Nigeria abdurrazakmadu@yahoo.com
\end{abstract}

\author{
Doi:10.5901/mjss.2015.v6n6s4p110
}

\begin{abstract}
The pre-reforms period of the Nigeria's Corporate Affairs Commission (C.A.C) was characterized by lack of standing system of tracking of companies' compliance and general gross inefficiency in the delivery of services by the Commission. In 2001 CAC experienced reform and re-organization processes; meant to make it more responsive to discharging its regulatory role and achieving good corporate governance practices and efficiency in service delivery. The question is, has these processes strengthened the quality of services delivered by the Commission? The objectives of this paper are to highlight the components of the re-organization exercise of C.A.C and see how the reform has impacted on the Commissions' performance. To achieve these, the paper employs the use of both empirical and secondary sources of data for analysis. The Service Quality Model was used as theoretical guide to the study. It was observed that the Commissions' reform and re-organization has impacted in computerization of company registration process, improved human resource quality and even the introduction of new services. The paper, therefore, recommends that for good corporate governance practices to be achieved in Nigeria, the C.A.C should continue to strengthen its compliance and enforcement processes and procedures and also ensure that all the registered companies are continually monitored and sanctions enforced on defaulters. When compliance and enforcement mechanisms are reinforced, the Nigeria's C.A.C would raise the confidence of investors and general public.
\end{abstract}

Keywords: Reforms; re-organization; corporate governance; service delivery; Nigeria and CAC.

\section{Introduction}

In our today's competitive business world, issues of corporate governance have gained increased prominence in countries around the globe. The soundness of corporate governance in any nation depends on its regulatory frameworks being put in place. In theory and in practice, regulatory bodies exercise their duties by imposing requirements, restrictions and conditions; setting standards of performance and securing of compliance, or enforcement amongst other functions. To carry out such regulatory functions "the Nigeria's Corporate Affairs Commission (C.A.C) was established based on the Companies and Allied Matters Act (CAMA), which was enacted in 1990; to regulate the formation and management of companies" (Ebenezer \& Omoneye, 2014; and C.A.C, 2005). However, prior to the reform of 2001, the operations of C.A.C was characterized by lack of standing system of tracking of companies' compliance with the Commission's standards hence, non-registered companies operating in the economy on the one hand, and the concentration of authority to approve names on the other, has made service delivery difficult to achieve. With the above susceptibility, investors tend to lose confidence on investments in companies operating in Nigeria and should have the tribulations allowed continuing, the economy of Nigeria would have dismally lost investment opportunities and can to a greater extent, threaten economic progress. Given this key presumption, the needs for the reforms in the C.A.C were discernible.

Whether in public or private sector, reform efforts are specifically made to promote institutional capacity for improved performance. Reforms especially in regulatory agency like the Nigeria's C.A.C are geared towards promoting organizational effectiveness through eliminating the cumbersome procedures that cause delays in operational activities. Caiden (1978, \& 1991) and Turner \& Hulme (1997) have often described such process as de-bureaucratization. The concern of the paper is: has the 2001 re-organization process strengthened the quality of services delivered by the Corporate Affairs Commission in Nigeria?

The objectives of this paper are to highlight the components of the re-organization exercise of C.A.C and same see how they impact on the Commissions' performance in the delivery of services. The paper drew inferences from both 
theory and practice of service quality and service delivery in the public sector organizations. Structurally, the paper is separated into four major divisions. First is the introductory, the second conceptually highlights corporate governance, regulatory bodies and service delivery and ends with framework of analysis. While the third section highlights reform components and discusses the paper, section four concludes it.

\section{Conceptual Review and Framework of Analysis}

The idea of corporate governance is associated with classical economic theory which laid much emphasis on the ways through which economic growth and development in an economy can be stimulated by individual and corporate investments. Corporate governance as rightly put by Demb \& Neubauer (1992), "is the process by which corporations are made responsive to the rights and wishes of stakeholders." As opined by Monks \& Minow (1995), "it is the relationship among various participants in determining the direction and performance of corporations." "Corporate governance addresses those issues boards of directors faces; as the interaction with top management, and relationships with the owners and others that are having to do with the affairs of the company; like the creditors, debt financiers, analysts, auditors and corporate regulators" (Tricker, 1994). Looking at it from similar perspectives; the American Law Institute (1992) states that, "the modern corporation by its nature creates interdependences with a variety of groups with whom the corporation has a legitimate concern, such as employee, customers, suppliers, and members of the communities in which the corporation operates." Furthermore, from the stewardship perspectives, however, "managers are good stewards of the corporations and diligently work to attain high levels of its profit and shareholders returns" (Donaldson \& Davis, 1994). Corporate governance as it relates to regulatory bodies is aptly captured by Cadbury (1992) as "the system through which corporations are directed and controlled."

According to Turnbull (1994 \& 1995) "the need for government bureaucracies to intercede as corporate regulators arises because those adversely affected by a firm may not have the information, power and will to correct the problem". Capital Ownership Group however maintained that, "the stakeholder participation in governance provides a way of reducing this deficiency. If the interests of the participating stakeholders are not sufficient to reflect the concerns of the host community; some government interventions will still be required. Moreover, stakeholder participation may also be required in government bureaucracies to allow policies to be mediated to suit local conditions and performance standards established and evaluated by those affected".

In order to achieve good corporate practices, regulatory bodies are established in any country. Examples of such regulatory bodies in Nigeria are- Nigeria Deposit Insurance Corporation (NDIC), National Electricity Regulatory Commission (NERC), Nigerian Communication Commission (NCC), Federal Board of Internal Revenue (FBIR), Teachers Registration Council of Nigeria (TRC), Standard Organization of Nigeria (SON), Security and Exchange Commission (SEC), Nigerian Investment Promotion Commission (NIPC), and Corporate Affairs Commission (C.A.C) to mention but these. In spite of the operations of these regulatory bodies (mentioned above), many Nigerian citizens have come to believe that services especially in public sector organizations cannot be improved due to strict adherence to bureaucratic procedures. For example, within governmental institutions, the occasion of staff hierarchy and chain of authority has not been particularly helpful as the system is still very much focused on command and control as against devolution of authority to front line managers who face practical service delivery situation on a day-to-day basis (SERVICOM, 2007). Service delivery as expressed by Stockton (2011) is about delivering services as effectively as possible to the satisfaction of the customers.

Franzini (2009) established amongst other things, "a strong relationship between extensive corporate governance and higher levels of aggregate investment; a relationship also exists between and corporate governance and higher growth levels". The study emphasizes the need for ensuring effective corporate governance framework applicable in our contemporary world. Although Franzini's findings is applied to Central and Eastern Europe because of their economic stability and sound regulatory frameworks, his findings may not apply to the situations in the less developed economies like Nigeria where regulatory bodies lack the ability to enforce compliance perhaps due to political interference which could in turn, affect their outputs in terms of quality of both staff and service delivery. In an attempt to contribute to knowledge, this paper attempts to examine the internal re-organizations to see how the reforms impact on Commission's service delivery.

In a related study, Kirfi, Abdullahi \& Idris (2013) established that "the reforms in C.AC has resulted in the computerization of operations, human resource management adjustment and adoption of a number of capacity building techniques in addition to strengthening the process of enforcement and compliance. The study concludes that, the enforcement of the C.A.C compliance arrangement was significant to ensuring the practice of corporate governance and service improvement. The study amongst others recommends that a new tracking system (electronic or manual) capable 
of identifying corporate concerns which negates the Commission's expectation should be put in place by adopting external intelligence or Corporate Citizen's Monitoring Unit (CCMU) and that the CAMA of 1990 must be modified to address both power and sanctions of the Unit. Although the study sought to report how compliance arrangement in the C.A.C affects corporate citizen's behaviour more than other aspects of services of the Commission, it did not examine the impact of the 2001 re-organization on corporate governance using service quality model. Therefore, this paper seeks to extend the frontier of knowledge by examining the impacts of the reform on corporate governance and quality services delivered by the Nigerian C.A.C.

This paper hinges on Service Quality (SERVQUAL) Model. According to Parasuraman, Zeithaml, \& Berry (1988), this model deals with an overall judgment towards the service delivery. SERVQUAL model emphasize on organization's ability to provide services efficiently and effectively. Irrespective of the type of organization, the model applies to a broad sphere of services. "SERVQUAL Model emphasized on evaluating the quality of a service by the customers on the following five (5) dimensions: reliability, responsiveness, assurance, empathy, and tangibles. Assurance- ability to instill confidence in customers; investors feel safe in their transactions; Reliability- provides services at the time promised; maintaining error-free records; Tangibles- have up-to-date equipment; Responsiveness- informs customers when services will be performed; offers prompt services to customers, and Empathy- employees given personal attention to all; employees having investor' best interest" (Ebenezer \& Omoneye, 2014).

The SERVQUAL model proposes that customers (investors and general public) can evaluate the quality of services rendered by organizations. In relation to this paper, the relationship between the quality of service citizens enjoy, and competence the regulatory bodies exhibited are very significant. Hence, the model can be used to explain reorganization reforms in regulatory bodies and on the other hand, measure the quality of services they provide to the customers. Accordingly, with the re-organization exercise, services rendered by the Commission become more reliable, responsive and assured. In particular, the reform enabled the CAC to run its business in accordance with global best practices which are the end results of the 5 dimensions of the SERVIQUAL model. Also, the computerization exercise facilitates the operations of the Commission to deliver its services timely, more affordable and in a pro-active manner. This is judged by the Commission's ability to conduct its business in the most efficient and effective manner.

\section{Highlights of the CAC Reforms and Discussion}

The essential features of the 2001 reform in the Nigeria's C.A.C were aimed at strengthening the quality of the services delivered by Commission. In terms of company registration, the hitherto manually paper-based procedures were replaced with electronically-based system. Customers now simply make payments for incorporation through e-payment system called Smart Card Technology (SCT). With this development, customers do receive the Commission's services from anywhere in Nigeria and the services are available Twenty-four (24) hours daily. This reduces the cost of incorporation including other logistics. Prior to the 2001 reorganization process, records were stored manually; the new allows for generating data of all the registered companies in Nigeria. Available records showed that the C.A.C had over 600,000 registered companies and has converted all the manually records to the electronically-based system. Simply put, the Commission's Information Management System greatly improved and this has provided foreign investors, the opportunities to conduct searches in their business concerns from anywhere around the globe. Contrary to the hitherto five-day term for registration, the reform also made C.A.C to introduce a Twenty-four (24) hours delivery service, a special registration for individuals or corporate bodies that require the special service. These amongst other aspects of the reform greatly improved the quality of services delivered by Commission.

From the foregoing reform highlights of the Nigeria's C.A.C, the following summary appeared more glaring: first, the reforms in the C.A.C resulted in the introduction of computer-based incorporation. Secondly, the reforms also provide an opportunity for investors (locally and internationally), more investment opportunities. Thirdly, another positive aspect of the reforms is the Commission's ability to conduct its business more transparently as investors and general public can access easily, the Commission's major operations through the internet services. Empirical evidence also reveals that the reform efforts led to significant improvement in the delivery of services through effective monitoring and enforcement of compliance. The Commission's action (de-listing) of Fifteen Thousand Four Hundred and Nine $(15,409)$ companies that have not complied with the Commission's requirements is an indication of the Commission's strive to meet up with international standards of best practice (Kirfi, 2011). Fourthly and finally, it is observed that the C.A.C-Online Project is geared towards improving efficiency; enhancing quality of service delivery and global best practices. Furthermore, according to the C.A.C (cac.gov.ng) "through the reform, customers pay and obtain the Commission's services through the internet. This is accessible using an e-cash Payment System based on Smart Card Technology such as the C.A.C epayment Card and Credit Card". It is worthy of note that, as a result of these, the complex and unnecessary delays in 
procedures associated with company registration has been overcome. It also, takes three days or less to complete the registration of a company. These also, make the Commission introduced "Same Day Incorporation Service for customers who wish to get express services within one day at a fee. Also, the process of registering incorporated trustees has changed from what was obtainable as trustee declaration form was introduced to supersede the former requirement of obtaining letter from State Security Service which encourages corruption as well as taking longer time to accomplish" (cac.gov.ng).

\section{Conclusion}

It is evident that in 2001, re-organization process had taken place in the Nigeria's Corporate Affairs Commission which ushered in a regime change in the delivery of services. The paper submits that this institutional reform has dramatically heightened the standard of the Commission. To further confirm the above statement, the reform effort has in many regards engrossed commendations locally and internationally. For instance, locally, the House of Representatives Committee on Commerce highly praised the untiring efforts in transforming the C.A.C for better services in the country. Internationally, "the C.A.C has received award for International Organization for Standardization, (ISO) 9001:2000 for Quality Management System, making the Commission one of the first government institutions in the country to obtain ISO Certification" (C.A.C, 2013). More so, the "World Bank in its 2008 Publication on Doing Business also commended the C.A.C's computerized registry amongst others". In spite of these achievements however, the paper therefore, offered the following recommendations:

First, partnership with registered and incorporated business on compliance arrangement should be re-enforced. This can be achieved by encouraging such companies to form leagues while the C.A.C exploits such leagues in monitoring all companies under the leagues. For meeting the requirements set for performance; registration with the Nigerian Investment Promotion Commission (NIPC) must be made compulsory by foreign investors for incorporation, and as usual, companies should register with the Nigeria's C.A.C, and for procurement of appropriate business permits, companies be made to be registered with the Nigerian Securities and Exchange Commission (SEC). When this arrangement is strengthen, enforcement of compliance would be easier, regulations guaranteed and improved service delivery by the C.A.C is ensured.

Lastly, the paper, therefore, submits that for good corporate governance practices to be achieved in Nigeria, the C.A.C should continue to strengthen its compliance and enforcement processes and procedures and also ensure that all the registered companies are continually monitored and sanctions enforced on defaulters. When compliance and enforcement mechanisms are reinforced, the Nigeria's C.A.C would raise the confidence of investors and general public. To prosecute these therefore, more autonomy be granted to the Commission in discharging its mandates.

\section{References}

American Law Institute, (1992). Principles of Corporate Governance: Analysis and Recommendations: Proposed Final Draft (March 31, 1992), The Institute, Philadelphia, PA.

Cadbury, A. (1992). Report of the Committee on the Financial Aspect of Corporate Governance, London, UK: Gee \& Co. Limited.

Caiden, G. E. (1978). Administrative Reform: A Prospectus, International Review of Administrative Sciences, Vol. XLIV, 106-120.

Caiden, G. E. (1991). Administrative Reform Comes of Age, New York: Walter de Gruyter.

Corporate Affairs Commission, (2005). Federal Republic of Nigeria, retrieved 04/05/13 @ http://www.cac.gov.ng/mb

Corporate Affairs Commission, (2013). Corporate Affairs Commission Proposes off the Shelf Companies, retrieved 04/05/13 @ http://www.cac.gov.ng/mb

Demb, A. \& Neubauer, F.F. (1992). The Corporate Board: Confronting the Paradoxes, Oxford University Press, Oxford.

Donaldson, L. \& Davis, J.H. (1994). Boards and Company Performance - Research Challenges the Conventional Wisdom, Corporate Governance: An International Review, 2 (3), 151-60.

Ebenezer, Y. A \& Omoneye O. O (2014). Corporate Governance Practice and Level of Compliance among Firms in Nigeria: Industry Analysis, Journal of Business and Retail Management Research (JBRMR) Vol. 9 Issue 1, 13-25.

Franzini, S. (2009). Corporate Governance in Theory and Practice, Journal of Politics and International Affairs, Spring, 77-93.

Kirfi, M.M.W. (2011). Capacity Building and Service Delivery in a Regulatory Bureaucracy: A study of Corporate Affairs Commission. A Ph.D Thesis in Busines Management, Postgraduate School, Usmanu Danfodiyo University, Sokoto.

Kirfi, M.M.W, Abdulsalam, N. K. \& Idris, S. (2013). Reforms in Regulatory Bureaucracy and Service Delivery in Nigeria: Evidence from Nigeria's Corporate Affairs Commission, Journal of Management Studies, U.D.U, Sokoto 1(1), 101-117.

Monks, R.A.G. \& Minow, N. (1995). Corporate Governance, Cambridge: Blackwell, MA.

Parasuraman, A., Zeithaml, V. A. \& Berry, L. L. (1988). SERVQUAL: A Multiple-item Scale for Measuring Consumer Perceptions of Service Quality, Journal of Retailing, 64 (1), 12-40. 
Servicom, (2007). History-Service Compact, Retrieved 18/12/13 @ http://www.servenigeria.com, 1-6.

Stockton, J. (2011). Service Implies a Degree of Excellence, Deliver it and the Sky is the Limit, retrieved 4/8/14 @ http://blog.myproject tracker.com/201/03/service-delivery/trackback

The Capital Ownership Group Virtual Think Tank; retrieved 05/08/15 @ www.cog.kent.edu

Tricker, R.I. (1994), International Corporate Governance, Singapore: Simon \& Schuster.

Turner, M. \& Hulme, D. (1997). Governance, Administration and Development: Making the State Work, New York: Palgrave.

Turnbull, S. (1994). Stakeholder Democracy: Redesigning the Governance of Firms and Bureaucracies, Journal of Socio-Economics, Fall, $23(3), 321-360$.

Turnbull, S. (1995). Corporate Governance, Harvard Business Review, May-June, 169-170. 